\section{(匹) \\ Check for updates}

Article Type: Research Paper

\title{
THE EFFECT OF EDUCATIONAL ATTAINMENT AND WORK EXPERIENCES ON EARNINGS IN INDONESIAN MANUFACTURING SECTORS
}

\author{
Khalifany Ash Shidiqi ${ }^{1,2 *}$ and Anggun Pasiya ${ }^{2}$
}

\begin{abstract}
This study examines the impact of educational attainment and work experiences on earnings of workers from the manufacturing sector in Indonesia. For the last seven years, this sector contributes the most GDP share (approximately more than 20\%) compared to other largest sectors namely agriculture, forestry, and fishery as well as wholesale and retail trades. Interestingly, manufacturing sector has the lowest number of workers compared to other mentioned sectors. Based on this comparison, manufacturing sector is likely requires workers who have a good educational background and work experiences. Moreover, workers in manufacturing sector have higher earnings compare to the other two sectors for almost all educational attainments and its rate is increasing along with the incremental of the level of education. The study estimates are based on the Mincerian wage equation with a large cross-section data of Indonesian Family Life Survey (IFLS) wave 5. The results show that educational attainment and work experiences are significantly and positively correlated with the earnings in both urban and rural area.
\end{abstract}

Keywords: Indonesian Manufacturing Sectors; Educational Attainment; Work Experiences; Indonesian Family Life Survey.

JEL Classification: 121; 126.

Shidiqi, K. A., \& Pasiya, A. (2019).

The Effect of Educational

Attainment and Work Experiences on Earnings in Indonesian Manufacturing Sectors. Jurnal Ekonomi \& Studi Pembangunan, 20(2), 151-162.

ARTICLE HISTORY

Received:

1 August 2019

Accepted:

22 October 2019

\section{Introduction}

Economists have developed the concept of development economics based on the production capacity of manpower, which was then known as an investment in human capital (Schultz, 1961). This concept assumes that human beings are a form of capital, which is reflected in the form of knowledge, idea, creativity, skills, and work productivity. Mankiw (2015) argued that education is an investment in human capital-the accumulation of investment in people such as education and on-the-job training.

In particular, when people have higher educational attainment, they will have a better quality in productivity (Khattak \& Khan, 2012). While there is an expansion in productivity, the economic growth will be increased as well, which then improve the economy in general and the welfare of the nation 
(see, for example, Hanushek \& Woessmann, 2010; Barro, 2013; Reza \& Widodo, 2013; Martiz \& Fourie, 2015 among many others). Since education has an important role in economic development in creating qualified human capital, therefore, investment in human capital (education) is paramount.

It is obvious that the investment in education cannot be done without any funding from the government. The government in many countries have emphasized that a high level of formal education is beneficial to the individual, society, and most importantly to the country itself. As it shown in figure 1, there are more than $10 \%$ of governments' spending is allocated for education and it has been increasing for the last 10 years. A similar trend is also happening in low, middle, and high-income countries.

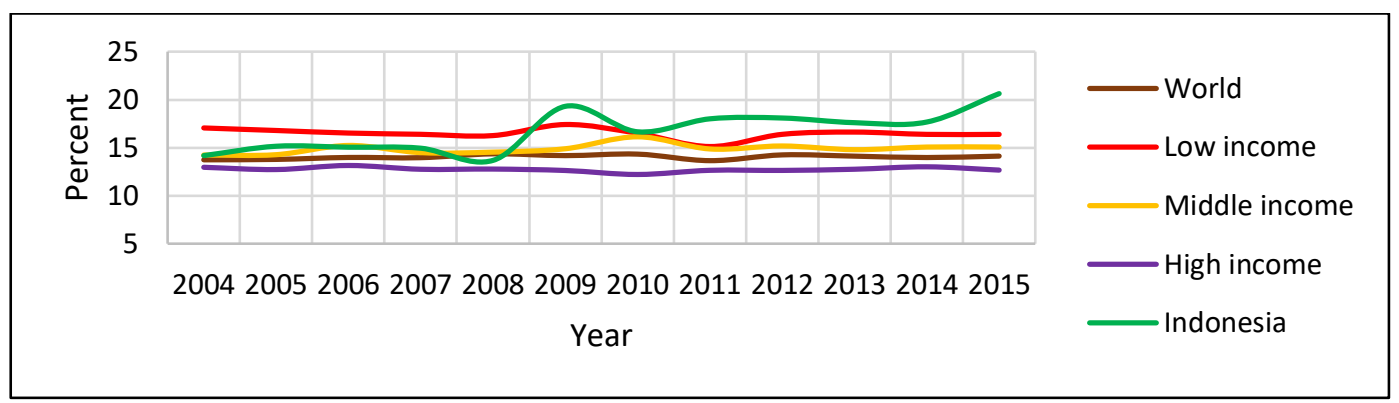

Figure 1 Government Expenditure on Education (Percent)

Source: World Bank (2018)

Interestingly, the Indonesian government put their concern on education excellently. As it shown in figure 1, the expenditure on education has been increasing significantly and it was reported at around $20.5 \%$ in 2015 , which is slightly greater than that stipulated in the 1945 Constitution of the Republic of Indonesia, article 31, paragraph 4. It is also compulsory for all Indonesian citizen to attain for at least 12 years of education. Moreover, there also exist an educational assistance fund through a joint program among ministries which is called Program Indonesia Pintar (PIP). This program begins in 2015 and aims to support pupils from poor families to be able to continue their education up to secondary school. In this case, the government, through PIP, seeks to prevent students from being a drop out of school because of financial problem. Based on this phenomenon, it appears that Indonesian government have a strong commitment in investing human capital through education.

Logically, it is obvious that by having higher educational attainment, people will hope for better future income. This statement has been proven scientifically that both education and earnings are positively correlated. This finding was pioneered by Mincer (1974). He clarified about the effect of educational attainment and work experience on earnings in which it is known as Mincer Earnings Model or Mincer equation. It has turned into a standard econometric model for income differences among people related with level of education and work experience. With the assumption that education and work experience are investment opportunity, Mincer (1974) acquired a straightforward and tractable econometric model in the form of a log-linear function. 
In its development, there are many works that focus heavily on the econometric issue of Mincerian model (see, for example, Card, 1995, 1999, 2001; Rosenzweig, 1995; Duflo, 2001; Heckman, Lochner, \& Todd, 2006; Lemieux, 2006; Oreopoulos, 2006 among many others). For instance, Card $(1995,1999)$ focused on the issues about identifying the relationship between schooling and earnings. Heckman et al. (2006) concentrated on empirical support using past and current data and on how to integrate future earnings uncertainty. Lemieux (2006) described the mechanism of current data that can be fit into the most common version of the Mincerian model. Those studies explain comprehensively on the fundamental model and economic rationale behind the Mincer equation, as well as its robustness and its importance to policy implementations.

Recent literatures about schooling rates of return have been measured for literally dozens of countries and for so many years. For instance, Kumbhakar (1996) showed that education rises actual productivity and its enhancement increased farmers' wages. Moreover, Psacharopoulos and Patrinos (2004) conducted a big survey which contains rate of return that utilizes for over 98 countries (including both developed and developing countries). They found that the rates of return to education tend to be higher in the developing countries than in developed countries. Interestingly, women tend to have a higher rate of return than men. The survey was also conducted by Gabriel and Schmitz (2005) by using data from the 2003 Current Population Survey in the U.S. labor market. They confirmed that additional year of schooling has a positive impact on the weekly earnings of men and women.

In Asia continent, The empirical analysis of Mincerian model in Asia continent, can be started by Johnson and Chow (1997). They used 1988 Chinese Household data and observed both for urban and rural area. Although they found that education and experiences positively affect income, but the rates of return to schooling is relatively low. In 21st century, Wannakrairoj (2013) estimated using the Mincerian model with a large cross-section data survey of Thai individuals. Wannakrairoj (2013) found that education and experience are positively correlated with the wages of labor in both urban and rural labor markets. Alsulami (2018) assessed Saudi individuals for both males or females who might be of the same age and work in the same field can gain different amounts of monthly salary due to different level of education. Alsulami (2018) found that the most two variables that significantly affect the Saudi salaries for both males and females are education qualification and the sector either public or private.

In Indonesia, the existing studies that utilized Mincerian model (for example, Taufiqurahman, 2013 and Santoso, 2017), were using Indonesian micro data such as Labor Force Situation Data (Sakernas) and Indonesian Family Life Survey. For instance, Taufiqurahman (2013) analyzed the impact of educational attainment, work experiences, on earnings by utilizing the Mincerian regression model. This research did not focus on specific sector (i.e. Agriculture, Trade, or Manufacturing) so that we believe Taufiqurahman (2013) was utilizing from all sectors in Indonesia. This research found that both educational attainment and work experiences significantly and positively affect individual income. 
The more specific sector regarding Mincerian model analysis can be found in Santoso (2017). This study estimated the impact of education levels, gender, ages, working hours, worker status and work experiences on workers' income in the trade sector in Indonesia. He concluded that all the independent variables are significantly and positively affect the level of income.

Based on the literature reviews described above, this paper evaluates the effect of educational attainment and work experiences on earnings in the Indonesian manufacturing sector by using data from the Indonesian Family Life Survey (IFLS) wave five. The IFLS provides rich data on individual's educational attainment, work experiences, monthly wage, and personal characteristics such as age, gender, health status, and marital status. By employing monthly wage as dependent variable and the two main independent variables such as educational attainment and work experiences, the analysis adopts Mincerian Earnings Model. The second part of this study briefly discusses the main literature used in this research. The part after that discusses the variables explanation, the data set, the estimation approach, and the regression result for Indonesia. In addition, the empirical analysis will be divided into three categories such as, estimation for all samples, for those who live in the urban area only and for those who live in the rural area only. The last part concludes.

The reason we analyze for the manufacturing sector is because first, we have not found any studies that specifically discuss about this sector in Indonesia. Second, there exists interesting phenomenon in Indonesia as it shown in figure 2 and 3 . The former figure shows that manufacturing sector has the lowest number of workers compared to agriculture, forestry and fishery as well as wholesale and retail trades, repair of motor vehicles, and motorcycles from 2010 to 2017. However, the latter figure declares that manufacturing sector contributes most to Indonesia's annual GDP growth (Statistics Indonesia, 2018). This sector has been contributing for more than $20 \%$ for the last seven years. Based on this comparison, this sector is likely requires workers who have a good educational background and work experiences as the main variables. Moreover, we also believe that those variables are matter for the earnings of the workers. As it shown in figure 4, workers in manufacturing sector have higher earnings compare to the other two sectors for almost all educational attainments and its rate is increasing along with the incremental of the level of education.

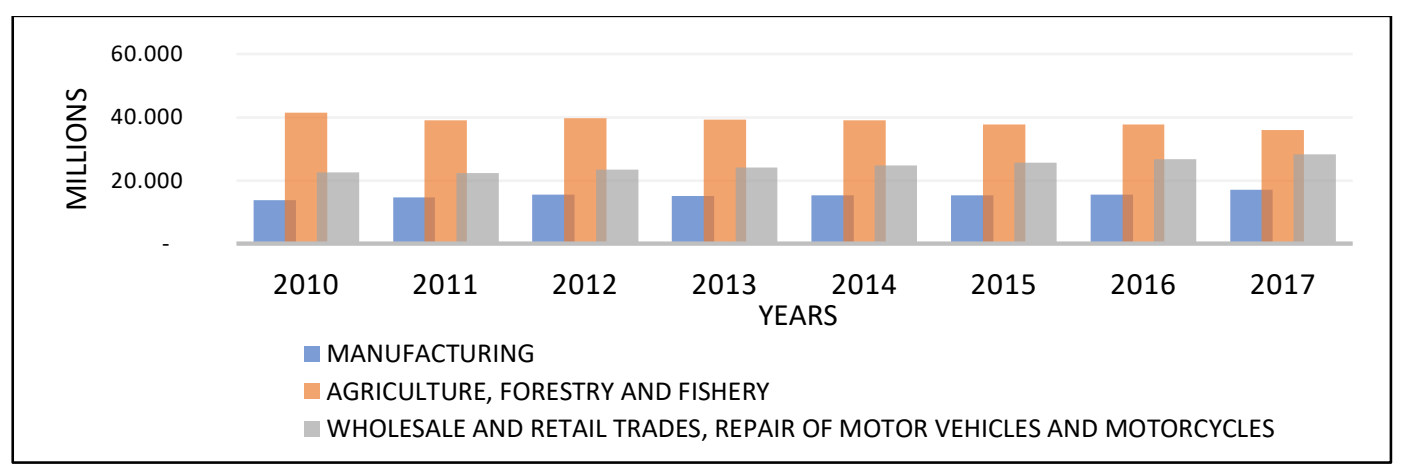

Figure 2 Number of Workers in Indonesian Top Three Sectors

Source: Statistics Indonesia, 2018 
The Effect of Educational Attainment and Work Experiences...

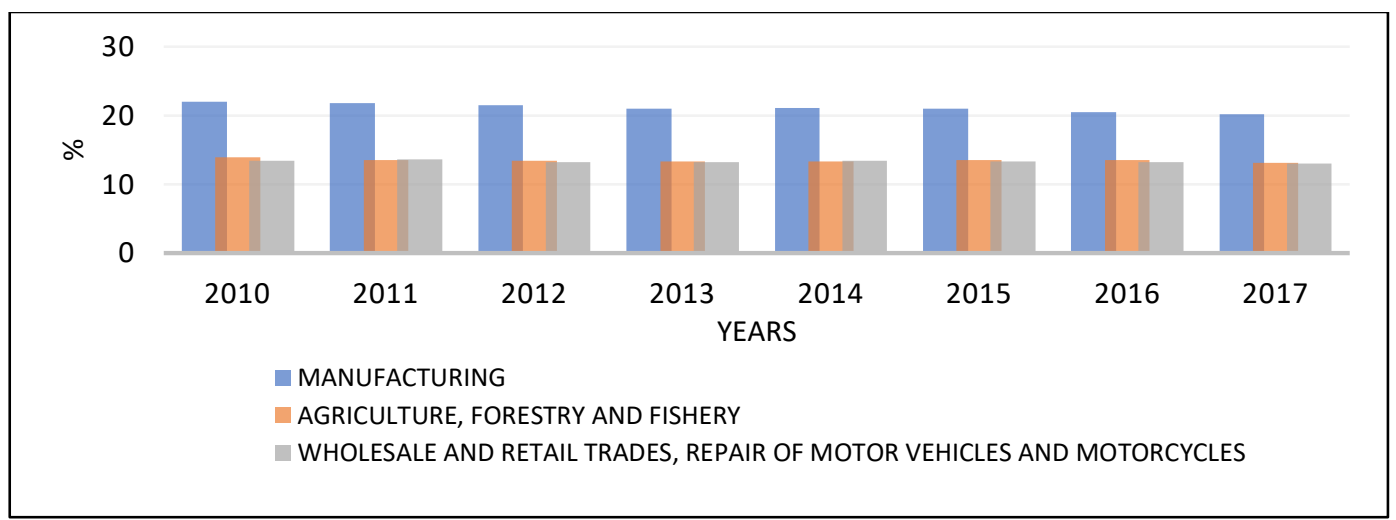

Figure 3 Contribution from Top Three Sectors to Indonesia's GDP Growth Source: Statistics Indonesia, 2018

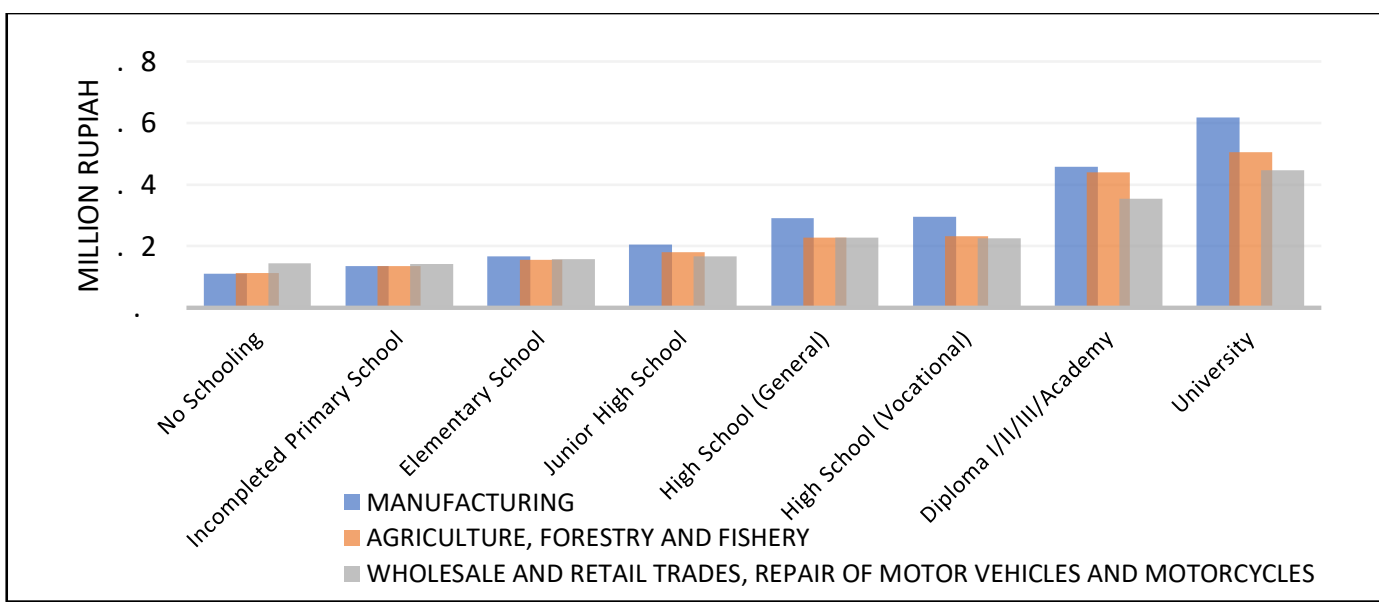

Figure 4 Average of Net Wage/Salary per Month of Employee by Educational Attainment and Main Occupation in Top Three Sectors (2017)

Source: Statistics Indonesia, 2018

\section{Research Method}
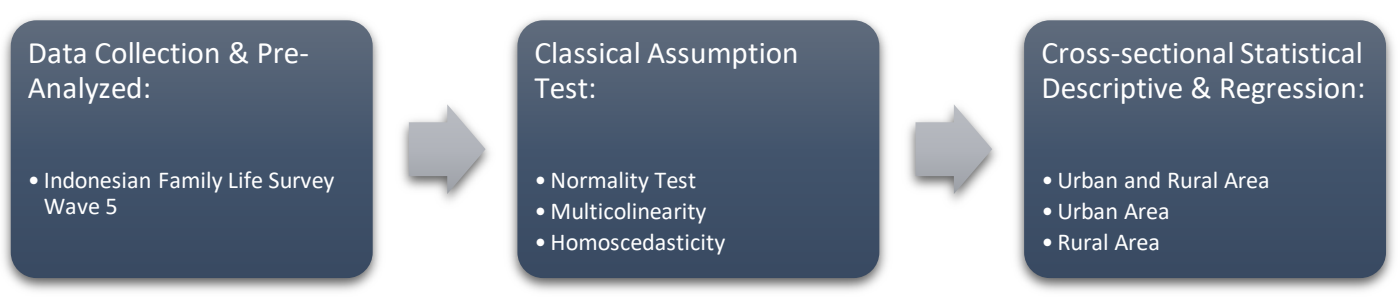

Figure 5 Scheme of Analysis

For the empirical analysis, this study uses cross-sectional data from the Indonesian Family Life Survey (IFLS) wave 5 which was sampled by RAND and available online in the following direction: https://www.rand.org/labor/FLS/IFLS.html. The dataset includes 30,000 
individuals living in 13 of 27 provinces in Indonesia. It covers information on self-reported monthly income, educational attainment, work experiences, and personal characteristics such as gender, age, and marital status. However, after we pre-analyzed the data that specifically for the manufacturing sector, we were able to use 1.580 observations. Considering the literature and availability of data, we employ a similar setup that was used by Johnson and Chow (1997) and Wannakrairoj (2013) for the model with urban and rural area and also Santoso (2017) for the use of specific economic sector as follows:

Monthly Earnings $=f($ Educational Attainment, Work Experiences, Social Variables $)$

Transforming into the econometric model used for estimating the effect of educational attainment and work experiences on earnings:

$\log Y_{i t}=\beta_{0}+\beta_{1} \operatorname{Educ}_{i t}+\beta_{2} \operatorname{Exp}_{i t}+\beta_{3}$ Gender $_{i t}+\beta_{4}$ Marital $_{i t}+\beta_{5}$ Age $_{i t}+\beta_{6}$ Age $_{i t}^{2}+\varepsilon_{i p}$

where $\log Y$ is the logarithm form of monthly earnings, $\beta_{0}$ is intercept term, $i$ and $t$ subscripts represent the individual $(i \in N)$ and region $(t \in T)$ respectively, $\beta_{1}$ to $\beta_{6}$ are the coefficient for the independent variables and $\varepsilon_{i p}$ stands for error term. Specifically, the description of the variables are as follows:

Table 1 Description of the variables used

\begin{tabular}{|c|c|}
\hline Variable Name & Description \\
\hline Earnings & $\begin{array}{l}\text { The monthly earnings of the individual between IDR } 500,000 \text { to IDR } \\
40,000,000\end{array}$ \\
\hline $\begin{array}{l}\text { Educational } \\
\text { Attainment }\end{array}$ & $\begin{array}{l}\text { A categorical variable that takes the following values: } 1 \text { (not } \\
\text { completed primary school), } 2 \text { (Primary Education), } 3 \text { (Junior High } \\
\text { School), } 4 \text { (Senior High School), } 5 \text { (Bachelor), and } 6 \text { (Postgraduate) }\end{array}$ \\
\hline $\begin{array}{l}\text { Work } \\
\text { Experience }\end{array}$ & $\begin{array}{l}\text { It is the total of work experience since the first time of working in the } \\
\text { manufacturing sector. It is expressed in units of years. }\end{array}$ \\
\hline Gender & Dummy variable: $1=$ male, $0=$ female \\
\hline Marital Status & Dummy variable: 1 (married), 0 = otherwise \\
\hline Age & Age of the individual in years between 15 to 65 years old \\
\hline
\end{tabular}

\section{Result and Discussion}

There are two estimation steps. First, we provide a descriptive analysis. Second, we estimate the equation above including control variables that also affect earnings according to the previous studies, along with the main variable such as educational attainment and work experiences. In particular, we present three similar models such as; model 1 , includes all individuals that live in the urban and rural area, while model 2 and 3 only individuals that live in the urban and rural area only. We also did the classical assumption test, which provided in the appendix. 
Shidiqi \& Pasiya

The Effect of Educational Attainment and Work Experiences...

Table 2 Earnings and Education, IFLS-5

\begin{tabular}{|c|c|c|c|c|c|}
\hline \multicolumn{6}{|l|}{ Earnings } \\
\hline Education & Obs & Mean & Std. Dev. & Min & Max \\
\hline Not Complete Primary School & 117 & $1,430,214$ & $1,178,743$ & 500,000 & $9,000,000$ \\
\hline Primary Education & 0 & 0 & 0 & 0 & 0 \\
\hline Junior High & 942 & $1,839,894$ & $1,373,173$ & 500,000 & $21,000,000$ \\
\hline Senior High & 395 & $2,413,542$ & $1,566,684$ & 500,000 & $13,500,000$ \\
\hline Bachelor & 127 & $3,600,512$ & $2,670,721$ & 500,000 & $15,000,000$ \\
\hline Postgraduate & 7 & $7,942,429$ & $6,917,162$ & $2,900,000$ & $23,000,000$ \\
\hline \multicolumn{6}{|c|}{ ANOVA $\mathrm{F}$ test for equal means $=29.57(0.00) * * *$} \\
\hline
\end{tabular}

Table 2 shows the higher response of earnings as the higher is educational attainment. For instance, the average earnings for individuals who have not completed their primary education is Rp. 1,430,214 while the average earnings for those who have completed senior high school and postgraduate is Rp. 2,413,542 and Rp. 7,942,429 respectively. Unfortunately, we did not find any individuals who are working in manufacturing sector that at least have been graduated from primary school. Moreover, according to the result of ANOVA F-test, we can reject the null hypothesis and initially suggest that there is a significant relationship earnings and educational attainment.

The main results presented in table 3 where we have three models as we explained above and suggest the following. We find that the most significant variable that gives the highest positive impact on Earnings is Educational attainment for all models. We use category of not completed primary school as the baseline. Thus, the earning for people who at least have obtained senior high school degree are higher by $0.475,0.454$, and 0.475 percentage points than those who have not completed primary school in model 1, model 2 , and model 3 respectively. The value of coefficients is also increasing as the educational attainment gets higher as well for all three models, which indicates the higher that individuals attain additional education level the higher the earnings they obtain. This result is in line with the finding of Johnson and Chow (1997) and Santoso (2017). Interestingly, the people who have at least postgraduate degree who are working in manufacturing sector are enjoying the most effect. However, this impact cannot be seen in rural area, since the number of people with that status is zero in the area mentioned. In addition, the effect of education on earnings for people who live in urban area are greater than those who live in rural area.

The impact of work experiences on earnings is quite small despite the coefficient in all area are positive. This finding is in line with Wannakrairoj (2013), however there exist a slight difference with our result. From regression output, the impact of work experiences for the people who live in rural area is higher than those who live in urban area to some extent. This result differs with the one in Wannakrairoj (2013) where the effect is higher in urban area. 
Shidiqi \& Pasiya

The Effect of Educational Attainment and Work Experiences...

Table 3 Ordinary Least Square, Earnings, Educational Attainment, Work Experiences and Socio-Economic Variables

\begin{tabular}{|c|c|c|c|}
\hline Variable & $\begin{array}{c}\text { Model } 1 \\
\text { Urban and Rural }\end{array}$ & $\begin{array}{c}\text { Model } 2 \\
\text { Urban Only }\end{array}$ & $\begin{array}{c}\text { Model } 3 \\
\text { Rural Only }\end{array}$ \\
\hline \multicolumn{4}{|l|}{ Education } \\
\hline \multicolumn{4}{|c|}{ Not Completed Primary School } \\
\hline Junior High & $\begin{array}{l}0.218 * * * \\
(0.057)\end{array}$ & $\begin{array}{l}0.206 * * * \\
(0.071)\end{array}$ & $\begin{array}{l}0.229 * * \\
(0.103)\end{array}$ \\
\hline Senior High & $\begin{array}{l}0.475 * * * \\
(0.062)\end{array}$ & $\begin{array}{l}0.454 * * * \\
(0.075)\end{array}$ & $\begin{array}{l}0.475 * * * \\
(0.115)\end{array}$ \\
\hline Bachelor & $\begin{array}{l}0.704 * * * \\
(0.788)\end{array}$ & $\begin{array}{l}0.706 * * * \\
(0.091)\end{array}$ & $\begin{array}{l}0.500 * * * \\
(0.162)\end{array}$ \\
\hline Postgraduate & $\begin{array}{l}1.767 * * * \\
(0.279)\end{array}$ & $\begin{array}{l}1.739 * * * \\
(0.278)\end{array}$ & \\
\hline Work Experiences & $\begin{array}{l}0.014 * * * \\
(0.004)\end{array}$ & $\begin{array}{l}0.011 * * \\
(0.005)\end{array}$ & $\begin{array}{l}0.019 * * \\
(0.008)\end{array}$ \\
\hline \multicolumn{4}{|l|}{ Gender } \\
\hline \multicolumn{4}{|l|}{ Female } \\
\hline Male & $\begin{array}{l}0.181 * * * \\
(0.031)\end{array}$ & $\begin{array}{l}0.246 * * * \\
(0.037)\end{array}$ & $\begin{array}{l}-0.005 \\
(0.062)\end{array}$ \\
\hline \multicolumn{4}{|l|}{ Marital } \\
\hline \multicolumn{4}{|l|}{ Unmarried } \\
\hline Married & $\begin{array}{l}0.071 * \\
(0.039)\end{array}$ & $\begin{array}{l}0.085 * \\
(0.045)\end{array}$ & $\begin{array}{l}0.014 \\
(0.085)\end{array}$ \\
\hline age & $\begin{array}{l}0.021 * \\
(0.011)\end{array}$ & $\begin{array}{l}0.023 * \\
(0.013)\end{array}$ & $\begin{array}{l}0.012 \\
(0.021)\end{array}$ \\
\hline $\operatorname{age}^{2}$ & $-0.0003 *(0.0001)$ & $\begin{array}{l}-0.0003 * \\
(0.0002)\end{array}$ & $\begin{array}{l}-0.0001 \\
(0.0003)\end{array}$ \\
\hline Number of Observation & 1,552 & 1148 & 404 \\
\hline $\mathbf{R}^{\mathbf{2}}$ & 0.1376 & 0.1606 & 0.0699 \\
\hline
\end{tabular}

Other social variables such as gender, marital status, and age give the following results. Earnings tend to be greater for men who are married rather than women. However, the significant effect only for those who live in urban area. Lastly, we find a positive effect of variable age on earnings with age-square coefficient that is also significantly less than zero, indicating the diminishing return of age as the people becomes older. Once again, this effect only for people who live in urban area.

\section{Conclusion}

Since Indonesia, as a developing country, has been in a time of profoundly fast development for the most part in the urban area, there has been a sensational contrast between labor markets in urban and rural area, bringing in a gap of earnings distribution across regions of the country. In this manner, accordingly, earnings structure was additionally not uniform across the country. This study provides the empirical evidences, based on the OLS regression of Mincerian model that supports the significant correlations between educational attainment and work experience on earnings in the manufacturing sector in Indonesia. The empirical results of this paper suggest that there exists a strong, positive, and significant relationship between education, work experiences, and earnings. 
Inside that, the results also reveal the difference of this relationship in urban and rural area.

As introduced in the outcomes, the coefficient of education is moderately huge, contrasted with the coefficient of work experience variable. Interestingly, the coefficients for education variable are the most elevated for the people who have at least postgraduate degree. This illustrates that people who have that sort of degree and currently working in manufacturing sector in urban area are enjoying high earnings. However, the impact is to some degree distinctive with previous literature in which the coefficient for work experience variable for the people who live in rural area is slightly higher than those who live in urban area. For the controls, we effectively estimated education and work experience variables by including social variables such as gender, marital status, and age. The results showed that those variables give positive impact on earnings only for the people who live in urban area.

Based on the results, there are several points that can be suggested for the government. First, the government can implement the educational reform by increasing the compulsory education policy from 9 to 12 years of education for all regions in Indonesia. This policy will be beneficial for all Indonesian people as their educational attainment increase will give them additional earnings. Second, in order to support the mentioned educational reform, the government must monitor and evaluate periodically regarding the effectiveness of the educational funding policy. This is very important, since the funding aims not just to improve the educational system but also to reduce the educational inequality across regions in Indonesia. In addition, the government may continue to improve the infrastructures so that people especially who live in rural area will have a good access to education.

This research is only utilizing the cross-sectional data from IFLS 5. Further study may employ a data panel estimation that includes other important factors, such as quality of education, internal referral job entry, or even other macroeconomics factors that might affect the earnings structure that were not incorporated into this study. Moreover, the use of quasi-experimental method might be more appropriate in estimating the Mincerian model.

\section{Acknowledgment}

The team of this study would like to thank to the Dean and Vice Dean of Faculty of Economics and Business, Universitas Muhammadiyah Yogyakarta (UMY) in supporting this research. Thank you also to the Head and Secretary of Department of Economics who always give support to us as well as LP3M UMY that bestow funding for this study. 


\section{Appendix}

\section{Heteroscedasticity test}

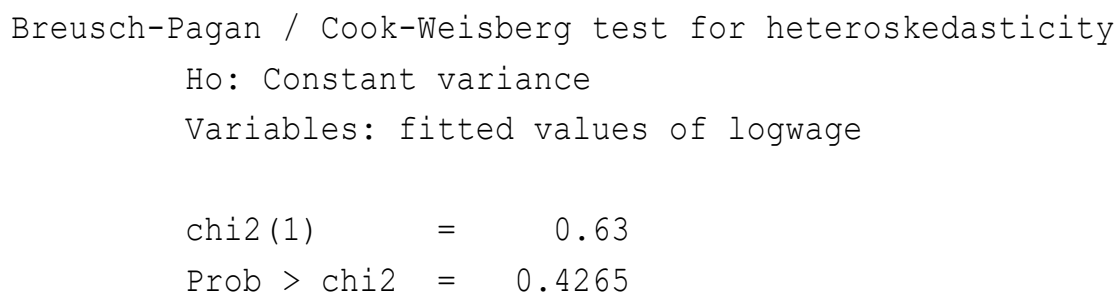

\section{Multicolinearity test}

\begin{tabular}{r|cr} 
Variable & VIF & $1 /$ VIF \\
\hline grad & & \\
3 & 3.95 & 0.253070 \\
4 & 3.64 & 0.274896 \\
5 & 2.04 & 0.491211 \\
6 & 1.04 & 0.960634 \\
exp & 1.04 & 0.966084 \\
$1 . \operatorname{male}$ & 1.02 & 0.977513 \\
$1 . m a r i t a l$ & 1.26 & 0.795906 \\
age & 1.41 & 0.711254 \\
\hline Mean VIF & 1.92 &
\end{tabular}

\section{References}

Alsulami, H. (2018). The Effect of Education and Experience on Wages: The Case Study of Saudi Arabia. American Journal of Industrial and Business Management, 8(1), 129-142. https://doi.org/10.4236/ajibm.2018.81008

Barro, R. J. (2013). Education and Economic Growth. Annals of Economics and Finance, 14(2), 301-328. Retrieved from

https://econpapers.repec.org/scripts/redir.pfu $=$ http $\% 3 \mathrm{~A} \% 2 \mathrm{~F} \% 2 \mathrm{Fdown}$. aefweb.net \%2FAefArticles \%2Faef140201Barro.pdf;h=repec:cuf:journl:y:2013:v:14:i:2:barro:educ ation

Card, D. (1995). Earnings, Schooling, and Ability Revisited. Research in Labor Economics, 14, 23-48. Retrieved from https://econpapers.repec.org/scripts/redir.pf?u $=$ http $\% 3 \mathrm{~A} \% 2 \mathrm{~F} \% 2 \mathrm{Fwww}$.nber.org $\% 2$ Fpapers\%2Fw4832.pdf; $\mathrm{h}=$ repec:nbr:nberwo:4832

Card, D. (1999). The Causal Effect of Education on Earnings. In O. Ashenfelter \& D. Card (Eds.), Handbook of Labor Economics (Vol. 3A, pp. 1801-1863). Amsterdam: Elsevier Press. https://doi.org/10.1016/s1573-4463(99)03011-4 
Card, D. (2001). Estimating the Return to Schooling: Progress on Some Persistent Econometric Problems. Econometrica, 69(5), 1127-1160. https://doi.org/10.1111/1468-0262.00237

Duflo, E. (2001). Schooling and Labor Market Consequences of School Construction in Indonesia: Evidence from an Unusual Policy Experiment. The American Economic Review, 91(4), 795-813. https://doi.org/10.1257/aer.91.4.795

Gabriel, P. E., \& Schmitz, S. (2005). A Note on Occupational Variations in the Returns to Education in the US Labor Market. International Journal of Manpower, 26(5), 450-456. https://doi.org/10.1108/01437720510615134

Hanushek, E. A., \& Woessmann, L. (2010). Education and Economic Growth. In D. J. Brewer \& P. J. McEwan (Eds.), International Encyclopedia of Education (Vol. 2, pp. 245252). Oxford: Elsevier. https://doi.org/10.1016/b978-0-08-044894-7.01227-6

Heckman, J. J., Lochner, L. J., \& Todd, P. E. (2006). Earnings functions, rates of return and treatment effects: The Mincer equation and beyond. In E. Hanushek \& F. Welch (Eds.), Handbook of the Economics of Education (Vol. 1). Amsterdam: Elsevier. https://doi.org/10.3386/w11544

Johnson, E. N., \& Chow, G. C. (1997). Education Return in Urban China: Evidence from CHNS Dataset. Education Return in Urban China: Evidence from CHNS Dataset, 2(2), $101-$ 113.

Khattak, N. U. R., \& Khan, J. (2012). The Contribution of Education To Economic Growth: Evidence from Pakistan. International Journal of Business and Social Science, 3(4), 145-151. http://www.ijbssnet.com/journals/Vol 3 No 4 Special_Issue February 2012/18.p df

Kumbhakar, S. C. (1996). A Farm-Level Study of Labor Use and Efficiency Wages in Indian Agriculture. Journal of Econometrics, 72(1-2), 177-195. https://doi.org/10.1016/03044076(94)01719-0

Lemieux, T. (2006). The "Mincer Equation" Thirty Years after Schooling, Experience, and Earnings. In S. A. Grossbard (Ed.), Jacob Mincer: A Pioneer of Modern Labor Economics (pp. 127-145). New York, NY: Springer Science.

Mankiw, N. G. (2015). Principles of Economics (7th ed.). Stamford: Cengage Learning.

Martiz, C. G., \& Fourie, A. (2015). Tertiary Education in South Africa: Is it Worth it? International Journal of Education Economics and Development, 6(2), 142-161. https://doi.org/10.1504/ijeed.2015.070628

Mincer, J. A. (1974). Schooling, Experience, and Earnings (1st ed.). Cambridge: Natonal Bureau of Economic Research. Retrieved from http://www.nber.org/books/minc 74-1

Oreopoulos, P. (2006). Estimating Average and Local Average Treatment Effects of Education when Compulsory Schooling Laws Really Matter. The American Economic Review, 96(1), 152-175. https://doi.org/10.1257/000282806776157641

Psacharopoulos, G., \& Patrinos, H. A. (2004). Returns to Investment in Education: A Further Update. Education Economics, 12(2), 111-134. https://doi.org/10.1080/0964529042000239140

Reza, F., \& Widodo, T. (2013). The Impact of Education on Economic Growth in Indonesia. Journal of Indonesian Economy and Business, 28(1), 23-44. https://doi.org/10.22146/jieb.6228

Rosenzweig, M. R. (1995). Why Are There Returns to Schooling? The American Economic Review, 85(2), 153-158. Retrieved from https://www.jstor.org/stable/2117910

Santoso, R. A. (2017). Analisis Determinan Pendapatan Tenaga Kerja Sektor Perdagangan di Indonesia Tahun 2014. Jurnal Pendidikan dan Ekonomi, 6(5), 510-519. Retrieved from http://journal.student.uny.ac.id/ojs/index.php/ekonomi/article/view/7208 


\section{Shidiqi \& Pasiya}

The Effect of Educational Attainment and Work Experiences...

Schultz, T. W. (1961). Investment in Human Capital. The American Economic Review, 51 (1), 1 17. Retrieved from https://www.jstor.org/stable/1818907?seq=1\#metadata info tab_contents

Taufiqurahman, E. (2013). Pengaruh Pendidikan dan Pengalaman Pada Pendapatan Rumah Tangga di Indonesia. Ekuitas: Jurnal Ekonomi dan Keuangan, 17(4), 451-467. http://dx.doi.org/10.24034/i25485024.y2013.v17.i4.114

Wannakrairoj, W. (2013). The Effect of Education and Experience on Wages: The Case Study of Thailand in 2012. Southeast Asian Journal of Economics, 1(1), $27-48$.

World Bank. (2018). Government expenditure on education, total (\% of GDP). Retrieved from: http://data.worldbank.org/indicator/SE.XPD.TOTL.GD.ZS 